\title{
Empirical Research on the Correlation between Corporate Social Responsibility and TMT Characteristics
}

\author{
Huimin Luo, Ling Wang \\ Department of Humanities and Economics \\ China University of Geosciences (Beijing) \\ Beijing, China \\ e-mail:pinko3127@163.com;e-mail: wang006699@163.com
}

Keywords: corporate social responsibility, TMT characteristics, stakeholders

\begin{abstract}
In recent years, problems like atmospheric haze, substandard milk powder and automobile recall have aroused people's attention to corporate social responsibility. There are differences between most enterprises' practical action of fulfilling social responsibility and the public's expectation, and TMT (top management team) is the major decision maker of an enterprise's behavior. Taking listed companies publishing the report on corporate social responsibility in 2014 as samples, this paper is aimed at studying the correlation between TMT characteristics and corporate social responsibility information disclosure. The results of empirical studies have shown that the proportion of the number of TMT with political and international background is significantly positively correlated to corporate social responsibility information disclosure, but there is no significant correlation between the number of TMT and corporate social responsibility information disclosure.
\end{abstract}

\section{Introduction}

In 2015, Under the Dome - a video about the survey on haze directed by Chai Jing aroused the public's attention to environment pollution caused by industrial enterprises. Before this, events like substandard milk powder in the dairy industry, automobile recall in the auto industry and price discrimination in the electronics industry made people attach importance to enterprises' fulfillment of social responsibility. Corporate social responsibility (CSR in short) means that an organization shoulders the responsibility for the impacts of its decisions and activities upon the society and environment through transparent and moral actions. [2] Apart from requiring the capitals invested by shareholders, an enterprise's survival also depends on all stakeholders including various resources providers, creditors and employees' devotions as well as the support from environment, government, consumers, communities and suppliers. Ever since a long time ago, there have been great gaps between most enterprises' actual action of social responsibility fulfillment and the public's expectation, and domestic and foreign scholars have always been studying the reasons for these differences.

At present, domestic and foreign studies on the factors influencing corporate social responsibility are mainly focused on the correlation among financial information disclosure, enterprise scale and shareholders' shareholdings. Since the company's TMT is the major decision maker of its way of act, that if the TMT's personal characteristic has influence on corporate social responsibility and what influence it has on it are topics worthy of exploration. [3] In recent years, scholars have started delving into the relations between corporate social responsibility and TMT characteristics. By taking the listed companies publishing the report on corporate social responsibility as samples, this paper controls the factors that may influence corporate social responsibility and conducts empirical test 
with regression analysis method from three aspects including the size of TMT, the political background of TMT and the internationalization level of TMT.

This paper's major contributions are following. First of all, very few literature can be found since current scholars have just started the study on the correlation between TMT characteristics and corporate social responsibility, thus this paper will enrich relevant studies on corporate social responsibility. Secondly, it is hard to directly obtain the indexes of corporate social responsibility since standard indexes have not yet been formed. Most scholars take Rankins CSR Ratings' data in 2011 and before years as the research sample, failing to reflect the latest correlation among variables. This paper selects the indexes of social responsibility disclosure published on hexun.com in 2014 to make up for the deficiencies of existing literature.

\section{Theoretical Analysis and Research Hypotheses}

Wherever Times is specified, Times Roman or Times New Roman may be used. If neither is available on your word processor, please use the font closest in appearance to Times. Avoid using bit-mapped fonts if possible. True-Type 1 or Open Type fonts are preferred. Please embed symbol fonts, as well, for math, etc.

- $\quad$ The Size of TMT (Number)

Enterprise administrators always make a decision in a complicated and fuzzy situation, and due to their different understanding of the decision-making circumstance, they make different decisions. [2] When the TMT scales up, information can be received more comprehensively, and different experiences and values will help administrators make more proper decisions, avoiding the onesidedness of one-person decision.

Hypothesis 1: The size of TMT is positively correlated to corporate social responsibility information disclosure.

- Political Background (Government)

An enterprise's development cannot be separated from the government's support. Fan et al. (2007) pointed out that the government could provide government-related enterprises with debt financing, lower tax rate and other benefits, and active response to the government's advocacy of shouldering social responsibility would bring better development to the enterprise. [1] If an enterprise has TMT members who have the experience in government work, they will tend to maintain corporate image and protect stakeholders.

Hypothesis 2: The number of TMT members with political background is positively correlated to corporate social responsibility information disclosure.

- International Background

The study on corporate social responsibility originates from western developed countries. In the west, enterprises pay much attention to stakeholders in addition to shareholders. Forbes and Fortune take "social responsibility" as one of the criteria for global enterprises' ranking. Carpenter and Fredrickson (2001) conducted studies from the perspective of social psychology and their results have shown that when the enterprise has low environmental uncertainty, TMT's international work experience and educational level heterogeneity can significantly promote the globalization strategy.[5]

Hypothesis 3: The number of TMT members with international background is positively correlated to corporate social responsibility information disclosure.

\section{Research Design}

\section{Samples Selection and Data Source}

This paper adopts top 100 listed companies in 2014 on the page of social responsibility disclosure on hexun.com as samples. In the process of sample selection:

(1) B-share listed companies are eliminated. B share is special Renminbi denominated share, its par value is marked by Renminbi, and it is purchased and sold as foreign currency, but since it is hard to get the information of foreign currency, this paper eliminates B-share listed companies. 
(2) Listed companies in the financial industry are eliminated. Most financial assets are priced in fair value, and assets in other industries are priced in historical cost. They are different pricing modes, so financial companies are eliminated.

(3) ST and ST* listed companies are eliminated. Enterprises of this type have suffered from losses for successive years, so their financial reports may be not true and fair.

(4) Companies with abnormal data are eliminated. Including those lacking relevant data and those having negative indexes of social responsibility,

Sample data is derived from the page of social responsibility disclosure on hexun.com, Guotai Junan Securities' database and all companies' annual reports. SPSS 21 is used for data analysis.

\section{Definition and Measurement of Variables}

1. Explained Variable: Corporate Social Responsibility Index (CSRID in short)

There are a variety of tools measuring corporate social responsibility, and frequently used tools include financial evaluation, reputation rating and index method.[5] Now most scholars adopt Rankins CSR Ratings' CSR Report, but this report hasn't been free to the public since 2011, thus it is hard to get its data. On September 13, 2013, social responsibility evaluation products of listed companies on hexun.com were on line. It was China's first social responsibility evaluation system constructed on the basis of objective and public data, and since it cooperated with Rankins CSR Ratings, its index system is of great reference.

This paper uses the corporate social responsibility information disclosure (CSRID) on hexun.com for measurement. To effectively measure dependent variables, the specialized evaluation system of listed companies' social responsibility report conducts the investigation from five aspects, namely, shareholders' responsibility, employees' responsibility, suppliers, customers and consumers' right and responsibility, environmental responsibility, and social responsibility. Moreover, second-class and third-class indexes are set respectively to give a full evaluation for social responsibility, involving 13 second-class indexes and 37 third-class indexes. Since this paper explores the correlation between TMT and other stakeholders' corporate social responsibility, it eliminates TMTrelated shareholders' contributions to social responsibility. In other words, the paper conducts the investigation from four aspects - employees' responsibility, suppliers, customers and consumers' right and responsibility, environment responsibility, and social responsibility.

2. Explaining Variable: TMT Characteristics

(1) The Size of TMT (Number)

To analyze this variable, the paper adopts the universal TMT in listed companies. TMT is inclusive of chairman of the broad of directors, director, independent director, non-executive director, chairman of the board of supervisors, supervisor, general manager, vice-general manager, chief financial officer, general manager assistant, chief engineer, chief accountant, chairman secretary, etc. The size of TMT refers to the sum of TMT with above titles published in the enterprise's annual report. [6]

(2) Political Background (Government)

To analyze this variable, this paper adopts the ratio of TMT members who are or used to be government official, deputy to the National People's Congress, and member of the CPPCC.

(3) International Background

To analyze this variable, this paper adopts the ratio of TMT members who have experience in following five aspects: foreign nationality, overseas education experience, overseas work experience, work experience in transnational enterprises, and membership of international or foreign organization.

3.Selection of C ontrol Variables

The enterprise's own factors also have important influence on corporate social responsibility information disclosure. This paper mainly selects three factors, namely, the enterprise's size, profitability and industry. Enterprise size is denoted by natural logarithm and enterprise profitability is denoted by the rate of return on equity. Industry attribute is dummy variable. Since pollution industries have less contribution to environmental responsibility than non-pollution industries, if the enterprise belongs to heavy-pollution industry stipulated by the State Environmental Protection Administration, it is 0 , otherwise, it is 1 . 


\begin{tabular}{ccc}
\hline Form 1 Definition of Various Variables \\
\hline \hline Explained Variables & Variables & Abbreviation \\
& $\begin{array}{c}\text { Responsibility } \\
\text { Information Disclosure }\end{array}$ & CSRID \\
& Size of TMT & Number \\
Explaining Variable & Political Background & Government \\
& International Background & International \\
& Total Assets & Size \\
& Rate of Return on Equity & ROE \\
Control Variables & Industry Attribute & Industry \\
& & \\
\hline \hline
\end{tabular}

\section{Model Design}

Based on above theoretical analysis and variables design, this paper uses regression analysis to test the correlation between listed companies' TMT characteristics and corporate social responsibility information disclosure, with regression model shown as below.

$$
\begin{aligned}
\text { CSRID }=\beta_{0} & +\beta_{1} \text { Number }+\beta_{2} \text { Government }+\beta_{3} \text { International }+\beta_{4} \text { Size } \\
& +\beta_{5} R O E+\beta_{6} \text { Ind }+\varepsilon
\end{aligned}
$$

\section{Empirical Results and Analysis}

\section{Descriptive Statistical Analysis}

According to the results of descriptive statistical analysis in Form 2, the maximum index value of samples' corporate social responsibility information disclosure is 0.62 and the minimum value is 0.07, which indicates that Chinese listed companies fulfill social responsibility to different degrees. Many listed companies have low index of social responsibility, showing that current enterprises just start to pay attention to social responsibility. The number of TMT is 11-35, and such an average number reveals that listed companies have convergent number of TMT. As for the political background and international level of TMT, there is great difference among various enterprises, but the standard deviation of political background is smaller than that of international level, showing that enterprises pay more attention to TMTs’ political experience but less attention to their international level.

Form 2. Statistics

\begin{tabular}{lllllll}
\hline \hline & CSRID & Number & Government & International & Size & ROE \\
\hline N Valid & 100 & 100 & 100 & 100 & 100 & 100 \\
Missing & 0 & 0 & 0 & 0 & 0 & 0 \\
Mean & .2218 & 16.6000 & .1015 & .0990 & 22.2923 & .1265 \\
Std. Deviation & .16690 & 3.83235 & .09974 & .11223 & 1.24168 & .09423 \\
Minimum & .07 & 11.00 & .00 & .00 & 20.13 & -.08 \\
Maximum & .62 & 35.00 & .38 & .67 & 26.33 & .69 \\
\hline \hline
\end{tabular}

\section{Correlation Test}

Form 3 reveals the result of Pearson correlation coefficients test of major variables, from which it can be seen that CSRID is significantly positively correlated to TMT's political background. The result primarily supports hypothesis 2 . ROE is significantly negatively correlated to CSRID, which shows that the better the enterprise's profitability is in current year, the worse its social responsibility information disclosure will be. Besides, the maximum value of Pearson correlation coefficients among variables is 0.485 (Pearson correlation coefficient between enterprise size and TMT size), which is far lower than the generally acknowledged critical standard 0.8. Therefore, there is no serious multicollinearity problem among various variables. 


\begin{tabular}{|c|c|c|c|c|c|c|c|c|}
\hline \multicolumn{9}{|c|}{ Form 3. Correlations } \\
\hline & & CSRID & Number & Government & $\begin{array}{c}\text { Internationa } \\
\text { | }\end{array}$ & Size & ROE & Indus try \\
\hline \multirow{3}{*}{ CSRID } & $\begin{array}{l}\text { Pears on } \\
\text { Correlation }\end{array}$ & 1 & 0.079 & $323^{-}$ & 0.192 & 0.171 & $-.212^{-}$ & 0.175 \\
\hline & $\begin{array}{l}\text { Sig. (2- } \\
\text { tailed) }\end{array}$ & & 0.433 & 0.001 & 0.058 & 0.088 & 0.035 & 0.082 \\
\hline & $\mathrm{N}$ & 100 & 100 & 100 & 100 & 100 & 100 & 100 \\
\hline \multirow{3}{*}{ Number } & $\begin{array}{l}\text { Pears on } \\
\text { Correlation }\end{array}$ & 0.079 & 1 & 0.172 & -0.125 & $.485^{-}$ & 0.023 & -0.168 \\
\hline & $\begin{array}{l}\text { Sig. (2- } \\
\text { tailed) }\end{array}$ & 0.433 & & 0.086 & 0.215 & 0 & 0.82 & 0.099 \\
\hline & $\mathrm{N}$ & 100 & 100 & 100 & 100 & 100 & 100 & 100 \\
\hline \multirow{3}{*}{ Government } & $\begin{array}{l}\text { Pears on } \\
\text { Corr elation }\end{array}$ & $.323^{-}$ & 0.172 & 1 & -0.132 & $.281^{-}$ & -0.092 & 0.012 \\
\hline & $\begin{array}{l}\text { Sig. (2- } \\
\text { tailed) }\end{array}$ & 0.001 & 0.086 & & 0.189 & 0.005 & 0.362 & 0.908 \\
\hline & $\mathrm{N}$ & 100 & 100 & 100 & 100 & 100 & 100 & 100 \\
\hline \multirow{3}{*}{ International } & $\begin{array}{l}\text { Pears on } \\
\text { Correlation }\end{array}$ & 0.192 & -0.125 & -0.132 & 1 & -0.031 & -0.008 & 0.023 \\
\hline & $\begin{array}{l}\text { Sig. (2- } \\
\text { tailed) }\end{array}$ & 0.058 & 0.215 & 0.189 & & 0.759 & 0.936 & 0.824 \\
\hline & $\mathrm{N}$ & 100 & 100 & 100 & 100 & 100 & 100 & 100 \\
\hline \multirow{3}{*}{ Size } & $\begin{array}{l}\text { Pears on } \\
\text { Correlation }\end{array}$ & 0.171 & $.485^{-}$ & $281^{-}$ & -0.031 & 1 & 0.108 & -0.12 \\
\hline & $\begin{array}{l}\text { Sig. (2- } \\
\text { tailed) }\end{array}$ & 0.088 & 0 & 0.005 & 0.759 & & 0.294 & 0.236 \\
\hline & $\mathrm{N}$ & 100 & 100 & 100 & 100 & 100 & 100 & 100 \\
\hline \multirow{3}{*}{ ROE } & $\begin{array}{l}\text { Pears on } \\
\text { Correlation }\end{array}$ & $-.212^{+}$ & 0.023 & -0.092 & -0.008 & 0.106 & 1 & -0.04 \\
\hline & $\begin{array}{l}\text { Sig. (2- } \\
\text { tailed) }\end{array}$ & 0.035 & 0.82 & 0.362 & 0.936 & 0.294 & & 0.691 \\
\hline & $\mathrm{N}$ & 100 & 100 & 100 & 100 & 100 & 100 & 100 \\
\hline \multirow{3}{*}{ Size } & $\begin{array}{l}\text { Pears on } \\
\text { Correlation }\end{array}$ & 0.175 & -0.188 & 0.012 & 0.023 & -0.12 & -0.04 & 1 \\
\hline & $\begin{array}{l}\text { Sig. (2- } \\
\text { tailed) }\end{array}$ & 0.082 & 0.099 & 0.908 & 0.824 & 0.236 & 0.691 & \\
\hline & $\mathrm{N}$ & 100 & 100 & 100 & 100 & 100 & 100 & 100 \\
\hline
\end{tabular}

\section{Regression Analysis}

The regression result of the model is shown in Form 4. The multicollinearity problem among variables can be tested by variance inflation coefficient (VIF). The larger the VIF value is, especially when it is greater than 10 , the more likely it will be to have the multicollinearity problem. In this paper, the VIF value of the model is 1.415 , far less than 10. Thus, both Pearson correlation analysis and VIF test results have revealed that there is no multicollinearity problem among variables. Moreover, the result of Form 4 also confirms the research hypotheses in this paper. According to the regression result:

There is no significant correlation between TMT size and social responsibility information disclosure. Thus, $\mathrm{H} 1$ is not confirmed.

The correlation coefficient between TMT's political background and social responsibility information disclosure reaches 0.494 , and the Sig value is 0.003 , less than 0.05 , thus passing the significance test. It indicates that the bigger the ratio of TMT with political background is, the better the corporate social responsibility information disclosure will be. Hence, $\mathrm{H} 2$ is supported by the data.

TMT's international level is significantly positively correlated to social responsibility information disclosure, and the correlation coefficient is 0.347 , thus passing the significance test.

It indicates that the bigger the ratio of TMT with international background is, the better the corporate social responsibility information disclosure will be. H3 is supported by the data.

ROE is significantly negatively correlated to social responsibility information disclosure, which may be because the enterprise sacrifices other stakeholders' interests for the purpose of maximizing the profits or maximizing the earnings per share, e.g. it may reduce staff welfare, oppress suppliers or deceive consumers, lower the consciousness of environmental protection, and lessen charitable donations, thus resulting in the lowered social responsibility information disclosure. 


\section{Form 4. Coefficientsa}

\begin{tabular}{|c|c|c|c|c|c|c|c|}
\hline \multirow[t]{2}{*}{ Model } & \multicolumn{2}{|c|}{$\begin{array}{l}\text { Unstandardized } \\
\text { Coefficients }\end{array}$} & \multirow{2}{*}{$\begin{array}{c}\begin{array}{c}\text { Standardized } \\
\text { Coefficients }\end{array} \\
\text { Beta }\end{array}$} & \multirow[t]{2}{*}{$t$} & \multirow[t]{2}{*}{ Sig. } & \multicolumn{2}{|c|}{$\begin{array}{l}\text { Collinearity } \\
\text { Statistics }\end{array}$} \\
\hline & B & Std. Error & & & & Tolerance & VIF \\
\hline (Constant) & -.243 & .293 & & -.830 & .409 & & \\
\hline Number & .001 & .005 & .033 & .312 & .756 & .740 & 1.352 \\
\hline Government & .494 & .161 & .295 & 3.066 & .003 & .888 & 1.126 \\
\hline International & .347 & .137 & .233 & 2.528 & .013 & .967 & 1.034 \\
\hline Size & .016 & .015 & .121 & 1.122 & .265 & .707 & 1.415 \\
\hline ROE & -.335 & .163 & -189 & $\begin{array}{c}-2.05 \\
3\end{array}$ & .043 & .971 & 1.030 \\
\hline Industry & .060 & .031 & .178 & 1.933 & .056 & .967 & 1.034 \\
\hline
\end{tabular}

\section{Conclusions and Inspirations}

From the perspective of TMT characteristics, this paper selects the data of Chinese listed companies in 2014 as samples to empirically study the correlation between TMT characteristics and corporate social responsibility, reaching following conclusions. Firstly, there is no significant correlation between the size of TMT and corporate social responsibility information disclosure, which may be caused by the distorted statistical information of TME number, e.g. some personnel have left the company, but the database has not yet been updated in time, thus affecting H1. Secondly, the ratio of TMT with political background is positively correlated to corporate social responsibility information disclosure, which further supports existing scholar's research conclusion (Huang Yanjuan, 2014). Thirdly, the ratio of TMT with international background is positively correlated to corporate social responsibility information disclosure. If the TMT has higher international level, it will increase the enterprise's awareness of fulfilling social responsibility. Meanwhile, the enterprise's ROE is significantly negatively correlated to corporate social responsibility information disclosure, indicating that the enterprise is likely to choose profit maximization rather than social responsibility fulfillment and sacrifice other stakeholders' interests. If so, it goes against the improvement of the enterprise's overall value, thus needing to arouse related personnel's attention.

The research conclusions of this paper are of some inspiring significance. Enterprises' social responsibility fulfillment is an irresistible trend when economy develops to a certain level, and the fulfillment of social responsibility in return enhances corporate image and achieves the maximum corporate value. To improve enterprises' social responsibility information disclosure, first of all, the government should play roles of guide and supervisor in the construction of corporate social responsibility information disclosure. Regarding immoral events of social responsibility, the government is required to establish corresponding corporate social responsibility mechanism as soon as possible.[7] Secondly, enterprises should focus on existing TMT members, encourage administrators to take part in political activities, and increase their international experience and values, so as to improve their sense of corporate social responsibility. Additionally, when selecting TMT members, enterprises should give consideration to the applicant's diverse backgrounds and make use of the differences in culture and values to add new vitality and maintain competitiveness in the rapidly developing economy.

There are still some defects of this research. Firstly, the sample size is not big enough, thus causing the limited results. Secondly, the materials obtained from database may be distorted in the measurement of TMT characteristics, so they should be revised manually through the financial reports in corresponding year. Hence, more progress in these aspects needs to be made in future studies. 


\section{References}

[1] Fan J P H, Wong T J and Zhang T Y. Politically Connected CEOs, Corporate Governance and Post IPO Performance of China's Newly Partially Privatized Firms. Journal of Financial Economics, 2007,84(2): 330-357.

[2] Niu Xiaoying. Research on Corporate Social Responsibility Accounting Information Disclosure of Listed Companies in Hebei Province [D]. Hebei: Hehei University, 2014

[3] Wu Lun. Ownership Concentration, Social Responsibility and Corporate Value - Empirical Test Based on Chinese Listed Banks [J]. Taxation and Economy, 2015, (2): 23-29.

[4] Huang Xiangfang, Zhou Wei. The Influence of TMT Characteristics on Corporate Social Responsibility - Empirical Test Based on Agricultural Listed Companies [J]. Journal of Inner Mongolia University of Finance and Economics, 2015, 13(2): 50-55.

[5] Huang Yanjuan. Empirical Study on the Correlation between TMT Characteristics and Corporate Social Responsibility Information Disclosure [D]. Sichuan: Southwest Jiaotong University, 2014.

[6] Shao Jie. Research on the Correlation between Administrator Characteristics and Corporate Social Responsibility Information Disclosure [D]. Henan: Henan University, 2014.

[7] Li Fei. Research on the Influence of TMT Characteristics on the Expense of Corporate Social Responsibility [D]. Heilongjiang: Harbin Institute of Technology, 2014.

[8] Hao Hailei. Listed Companies' TMT Characteristics - Research on the Influence of TMT Incentive on Enterprises’ R\&D Input [D]. Shaanxi: Xi'an University of Science and Technology, 2014.

[9] Zheng Guanqun. TMT Characteristics, Strategic Behaviors and the Quality of Corporate Social Responsibility Information Disclosure [J]. Economic Survey, 2015, 32(2): 111-116.

[10] Han Yutao. Empirical Research on the Influence of TMT Characteristics on Enterprises' Charitable Donation [D], Southwestern University of Finance and Economics, 2013. 